\title{
Influence of the Caiçaras on Soil Properties in the Savanna Region of Roraima, Northern Amazon
}

\author{
Ludmilla Verona C. Gonçalves ${ }^{1} \mathbb{1}$, Rachel C. Pinho ${ }^{2}$, Marta Iria C. Ayres ${ }^{3}{ }^{\mathbb{D}}$, Cesar A. Ticona-Benavente ${ }^{3}$, \\ Henrique dos Santos Pereira ${ }^{4}\left({ }^{\circ}\right.$, Afrânio F. Neves Junior ${ }^{4}$ and Sonia S. Alfaia ${ }^{3, *}$ \\ 1 Ministry of Agriculture, Livestock and Food Supply, Florianópolis 88102-600, Brazil; \\ lud_verona@yahoo.com.br \\ 2 Department of Territorial Indigenous Management, Federal University of Roraima, \\ Boa Vista 69310-000, Brazil; rachel.pinho@ufrr.br \\ 3 National Institute of Amazonian Research, Manaus 69060-001, Brazil; marta.ayres@hotmail.com (M.I.C.A.); \\ cesar.benavente@gmail.com (C.A.T.-B.) \\ 4 College of Agrarian Sciences, Federal University of Amazonas, Manaus Campus, Manaus 69067-005, Brazil; \\ henrique.pereira.ufam@gmail.com (H.d.S.P.); anevesj@@gmail.com (A.F.N.J.) \\ * Correspondence: sonia.alfaia@inpa.gov.br
}

check for

updates

Citation: Gonçalves, L.V.C.; Pinho, R.C.; Ayres, M.I.C.; Ticona-Benavente, C.A.; dos Santos Pereira, H.; Neves Junior, A.F.; Alfaia, S.S. Influence of the Caiçaras on Soil Properties in the Savanna Region of Roraima,

Northern Amazon. Sustainability 2021, 13, 11354. https://doi.org/10.3390/ su132011354

Academic Editor: Thierry Becquer

Received: 9 July 2021

Accepted: 14 September 2021

Published: 14 October 2021

Publisher's Note: MDPI stays neutral with regard to jurisdictional claims in published maps and institutional affiliations.

Copyright: (c) 2021 by the authors. Licensee MDPI, Basel, Switzerland. This article is an open access article distributed under the terms and conditions of the Creative Commons Attribution (CC BY) license (https:/ / creativecommons.org/licenses/by/ $4.0 /)$.

\begin{abstract}
The management of caiçaras by indigenous peoples in the "Lavrado" (savannas) region of Roraima is a practice that increases soil fertility. Caiçaras are temporary corrals where farmers keep the cattle at night for a certain period, when the soil is enriched by manure addition. In periods when these areas are not used as corrals, they may be planted with different plants species. In addition, areas adjacent to caiçaras may receive manure runoff and also be used for crop production. The study evaluated the changes in soil physical and chemical characteristics resulting from manure supply and runoff in caiçara and adjacent areas and compared these to soil characteristics of nearby unmanaged areas. Soil samples from the three system components were analyzed. The nutrient content added by manure runoff in the plantation adjacent to the caiçara resulted in significant accumulations of organic $\mathrm{Ca}, \mathrm{Mg}, \mathrm{K}, \mathrm{P}, \mathrm{C}$, and micronutrients in the soil, without, however, changing $\mathrm{pH}$. Only the soil surface $(0-5 \mathrm{~cm})$ showed improvements in soil bulk density and total porosity. This soil management system proves how efficient indigenous farmers can be in integrating their livestock component with the exploitation of available resources to improve soil fertility in areas of low natural fertility, enhancing agricultural production.
\end{abstract}

Keywords: indigenous agriculture; livestock; organic fertilization; soil fertility

\section{Introduction}

The largest contiguous area of savannas in Amazonia, with 43,358 km², locally known as "Lavrado", is located in the north of the state of Roraima, Brazil [1,2]. This ecosystem is composed predominantly of open grassy vegetation with a low density of trees, but there are also areas with forest-like formations, such as palm forests, gallery forests along streams, and semi-deciduous forests in the form of islands, regionally known as 'forest islands' [3-5].

Soils in Lavrado have, in general, low base saturation and low cation exchange capacity, together characterized as low natural fertility, while forest-like formations have more fertile soils [6]. Additionally, some Lavrado areas have high aluminum saturation, which characterizes typically dystrophic and alic soils [7,8]. For those reasons, indigenous peoples of this region traditionally install their food production systems not in the areas of Lavrado but in forest-like formation areas to benefit from greater natural fertility [9]. These areas are mostly represented by semidecidous forest "islands" and are also used for logging, hunting, and other livelihood activities [10]. However, the non-forested Lavrado, although less diverse and with less fertile soils, is also widely managed by the local indigenous 
population, such as for agroforestry in homegardens [11] and, more recently, extensive livestock ranching [12,13].

The Lavrado, with its large open grasslands, is conducive to extensive cattle ranching $[14,15]$. The first cattle herds were brought by Portuguese colonizers in the 19th century, with the aim of "occupying" the region, resulting in the expulsion of many indigenous peoples from their territory and the creation of ranches [16]. Some indigenous people were hired to work in the ranches, not only learning the techniques of livestock raising but also getting used to the equipment, language, and lifestyle of immigrants. At the end of the decade of the 1970s, with the initial support of the Diocese of Roraima (the organization of the Catholic church) and later other organizations, the indigenous peoples themselves introduced cattle raising into their communities. This was to guarantee the ownership of their original lands that were being taken by the livestock ranchers and also to support their own local economies [13]. As a result, indigenous peoples of the Lavrado (savanna region) became extensive cattle ranchers, a practice that goes on today, with adaptations to the indigenous context [12]. More detailed aspects of the introduction of livestock among the indigenous peoples of the Lavrado have been well-described by other authors $[13,15,16]$.

Among the adaptations for cattle raising in Indigenous Lands (IL), there are the "caiçaras". According to [17], the term caiçara originates from the Tupi-Guarani caáiçara [18], used to name the stakes placed around indigenous communities or villages, as well as a corral made of tree branches fixed in the water to contain fish along the Brazilian coast. In the indigenous communities in the Lavrado, the caiçaras are also corrals, but used to hold cattle. Caiçara management is a practice inherited from the colonizers and used to hold cattle that are gathered every night for a few months, providing an accumulation of manure and, consequently, soil enrichment $[9,13]$

As with other itinerant corral systems observed in diverse pastoralist settings [19,20], when the caiçara is no longer used for livestock holding, the indigenous people take advantage of the enriched soil for planting various fruit and agricultural species. In addition to the production of manure as a fertilizer that can be transported and used in other production areas, crops grown in the caiçaras are important for food security in a system that has the advantage of not demanding the transport of manure [13].

As well as in other indigenous communities of the Lavrado region, in the Aningal community, cattle raising is extensive, that is, the herd remains dispersed in the fields during the day, and in the late afternoon, the cowboy herds them to sleep in the caiçara. The caiçara is more frequently used in the rainy season and, because it is a large area, it does not accumulate a large amount of mud, which would make work difficult for the cowboy. In the dry season, other smaller corrals are often used.

In the Aningal community specifically, where the research was carried out, the caiçara system receives yet another adaptation [13]. The caiçaras are installed in areas of slightly inclined terrain, causing part of the manure to run off to an area adjacent to the caiçara; it is in this adjacent area where planting is carried out. This adjacent area has the additional advantage of not "occupying" the caiçara with plants, allowing caiçara to be continuously used for cattle herding.

Caiçara management aims to increase soil fertility, using a source of nutrients that is easily accessible, and shows that traditional communities recreate efficient and low-cost alternatives to produce their food in formerly low-fertility soils. The following hypothesis has justified this study: the management caiçaras for indigenous peoples, as well as other anthropic actions in the environment, cause positive changes in the chemical and physical characteristics of the soil, resulting in changes in the landscape of the Lavrado. Considering these aspects, the objective of this study was to evaluate the changes in the chemical and physical characteristics of the soil, caused by the supply of bovine manure in caiçaras and in the adjacent cultivated areas that receive the manure that runs off from the caiçaras, and compare these with nearby areas that do not receive manure. 


\section{Materials and Methods}

\subsection{Study Area}

The research was carried out in the Aningal community (coordinates $61.40^{\circ} \mathrm{W}$ and $3.46^{\circ} \mathrm{N}$ ), located in Aningal Indigenous Land, which occupies an area of 7627 hectares [21] in the municipality of Amajari, northeastern Roraima, Brazil. In the Aningal community, there are approximately 160 people in 40 families, belonging to Macuxi, Wapichana, Taurepang, and Sapará ethnic groups.

In the Aningal community, there are areas far from the center of the community, regionally known as "retiros", where the community cowboy usually lives. In each retiro, there is a caiçara. For the study, three retiros (Aningal, Rebolada, and Saúba) were chosen, each of them with a caiçara and an adjacent planting area. The adjacent planting area is located in a place slightly lower than caiçara from where they receive manure run-off (Figure 1). Adjacent plantations are or have already been cultivated in areas with diversified plantings of fruit trees, legumes, and other plant species.

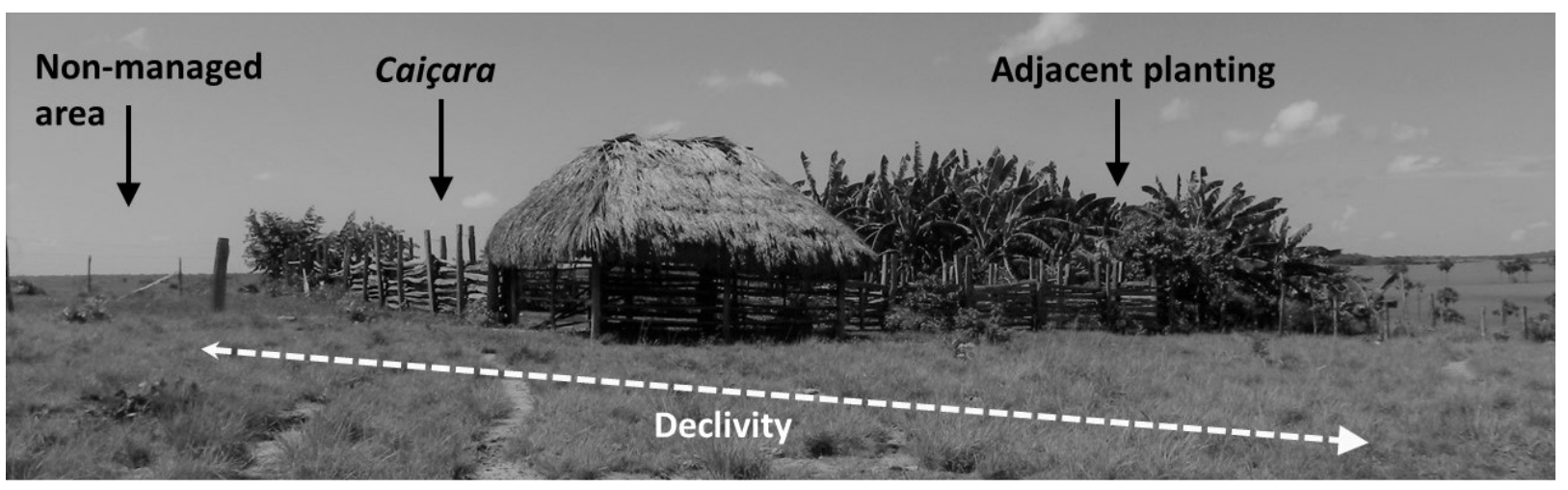

Figure 1. Caiçara management system in the retiro Aningal, indicating the sampled areas.

The history of the caiçaras and adjacent planting areas of three sites was reconstructed by interviewing the indigenous farmers. In retiro Aningal, which presents loamy sandy and loam soil textures, the sampled caiçara was approximately 18 years old, and by that moment, it was covered by a native invasive leguminous plant known as "mata-pasto" (Senna obtusifolia). Planting in its adjacent area began between 1999 and 2000 and, according to the indigenous peoples' statements collected during the study, it was once rich and diversified, but was then undergoing a process of degradation. This area was cultivated with some domesticated agricultural species (banana, guava, and pepper).

The caiçara in retiro Rebolada was installed in 2007, beside another caiçara built in 1995 and currently deactivated. The adjacent area has received run-off manure first from the deactivated caiçara and then from the current caiçara. The current planting of banana and pepper in the adjacent area began in 2003. The soil textural class in this retiro is predominantly sandy loam.

Retiro Saúba, with sandy clay loam soil, has a caiçara built in 2006, with an adjacent planting area installed in 2011, with a wide variety of banana, acerola, soursop, papaya, medicinal herbs, and condiments.

\subsection{Soil Sampling and Analysis}

Soil sampling was carried out during the dry season of January 2013, when the caiçaras were "resting", i.e., not being used to hold cattle. Each of the three retiros was split into the three following experimental units for soil collection: caiçara, the adjacent planting area, and the non-managed area (control). In each experimental unit, a sampling plot of $10 \times 15 \mathrm{~m}$, with three sub-plots $(10 \times 5 \mathrm{~m})$, was installed in the center. Five soil samples from each sub-plot were collected from the 0-10 and 10-20 cm layers, and three samples from the 20-30 cm layer; these samples were mixed to form sub-plot composites and 
analyzed separately, then averaged to represent the unit. The $\mathrm{pH}\left(\mathrm{H}_{2} \mathrm{O}\right.$ and $\left.\mathrm{KCl}\right)$, contents of exchangeable $\mathrm{Ca}, \mathrm{Mg}, \mathrm{K}, \mathrm{Al}$, available $\mathrm{P}$, organic $\mathrm{C}$, and exchangeable micronutrients $\mathrm{Cu}, \mathrm{Zn}, \mathrm{Mn}$, and Fe were measured according to the methodology proposed by [22]. The soil texture was determined using the rapid dispersion method in accordance with the methodology described by Embrapa [22] based on the American Soil Texture Triangle adapted by the Brazilian Soil Science Society [23].

Soil bulk density was measured with two undeformed samples from each plot, collected at $0-5 \mathrm{~cm}$ and $5-10 \mathrm{~cm}$ depths, with $5 \mathrm{~cm}$ diameter and $5 \mathrm{~cm}$ height volumetric rings. The volumetric rings were oven-dried at $105^{\circ} \mathrm{C}$ for $48 \mathrm{~h}$. After drying, the soil mass was determined, and the soil bulk density (Ds) and total soil porosity (TP) were calculated following the methodology described by Embrapa [22].

\subsection{Statistical Data Analysis}

Experimental design consisted of randomized blocks with three treatments: caiçara, adjacent planting, and non-managed area (control), and three blocks (=3 retiros). Statistical significance was determined by analysis of variance with Duncan's test at $5 \%$ probability. The results were analyzed using the SAS 9.0 (SAS Institute Inc., Cary, NC, USA). Principal component analyses were used to observe the general distribution of variables for soil, communities, and management systems. The standardized averages of each soil variable were used to generate biplot graphics. The graphical analyses were performed using the JMP 10 program (SAS Institute Inc., Cary, NC, USA).

\section{Results}

\subsection{Acidity, Exchangeable Al, $\mathrm{Ca}, \mathrm{Mg}, \mathrm{K}$, Available P, and Organic C}

Except for $\mathrm{pH}(\mathrm{KCl})$ at the $0-10 \mathrm{~cm}$ layer, in general, $\mathrm{pH}$ did not change significantly among the different land use systems sampled (Figure 2).

Levels of exchangeable Al were considered low in most of the soils analyzed, in contrast to what is observed in most soils in the Amazon [24]. In depths of 0-10 and 10-20 cm, they were significantly higher in the non-managed area.

In the three depths, there was a significant increase in Ca levels in the adjacent planting areas, compared to the soils of caiçaras and non-managed areas. At the $0-10 \mathrm{~cm}$ depth, the Ca level in the planting area increased about six and three times compared to the non-managed areas and caiçaras, respectively. There was also a significant increase of $\mathrm{Mg}$ in the planting areas compared to the caiçaras and non-managed areas. At a depth of $0-10 \mathrm{~cm}$, levels were five times higher than in non-managed areas and two times higher than in the caiçara.

For the three sampled depths, planting areas' soils had significantly higher levels of $\mathrm{K}$ than the caiçaras and non-managed areas. These data indicate how the management practices carried out in the caiçaras, associated with an adjacent planting area, can significantly increase the level of this nutrient in soils of the Lavrado. P levels in planting areas were significantly higher than in other areas. In these areas, available $P$ increased by 30 times at a depth of $0-10 \mathrm{~cm}$ and 27 times in the other depths, compared to non-managed areas.

There was a significant increase in levels of organic $C$ of soil, comparing adjacent planting areas to the other experimental units. In the depth of $0-10 \mathrm{~cm}$, this $C$ rise was about four times greater in the adjacent planting area compared to the non-managed area. 

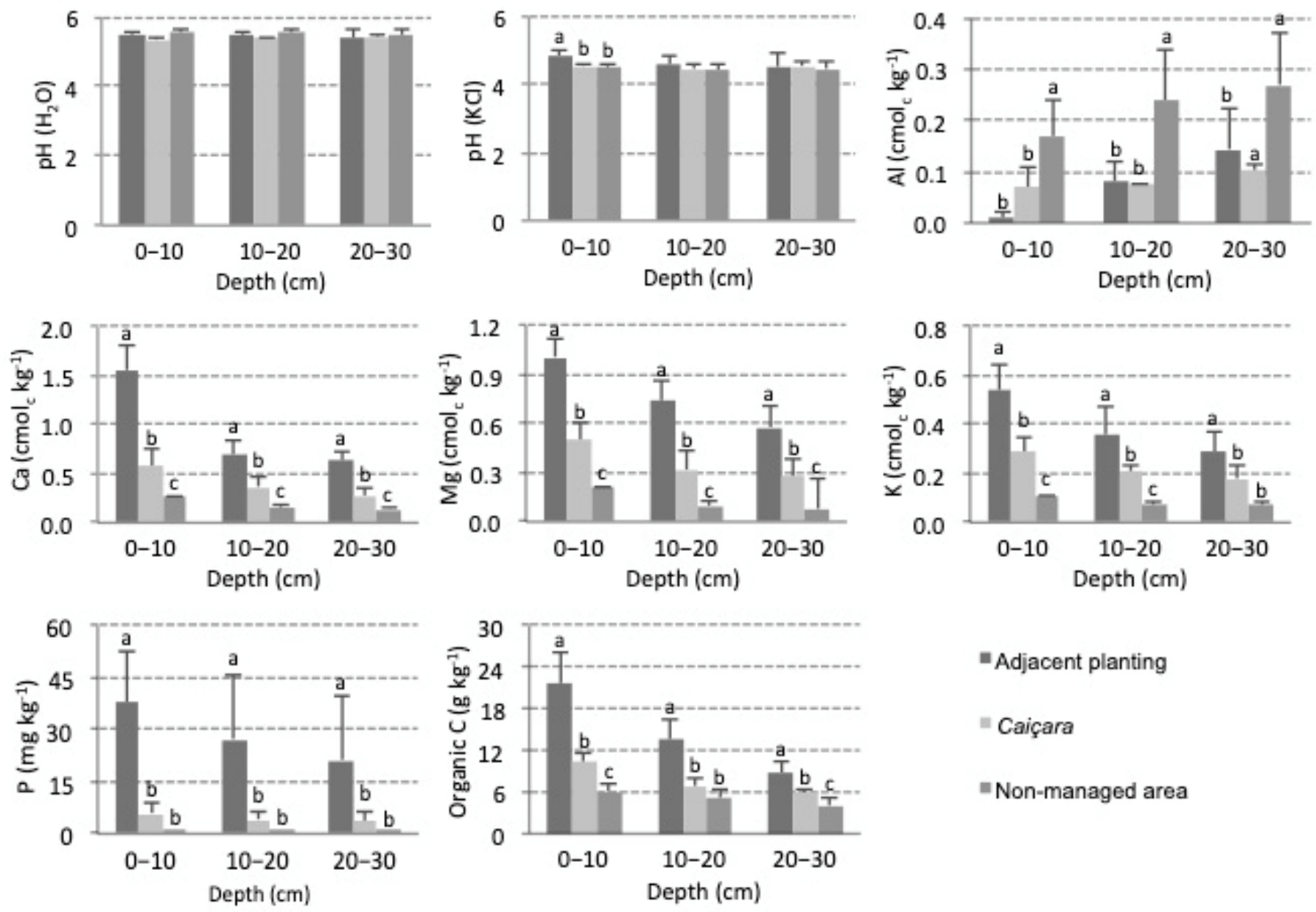

Figure 2. Average values of $\mathrm{pH}, \mathrm{Al}, \mathrm{Ca}, \mathrm{Mg}, \mathrm{K}, \mathrm{P}$, and organic $\mathrm{C}$ in three land use systems in Aningal Indigenous Land, Roraima. Columns represent the mean of three sites and lines the standard error of the mean. Subsequent columns with the same letter, at the same depth, do not differ from each other at the level of 5\% probability by the Duncan's test.

\subsection{Micronutrients ( $\mathrm{Cu}, \mathrm{Zn}, \mathrm{Mn}$, and $\mathrm{Fe})$}

There was no significant difference for $\mathrm{Cu}$ levels in the three systems studied (Table 1). In contrast, levels of $\mathrm{Zn}$ and $\mathrm{Mn}$ are higher in the planting areas than in caiçaras and non-managed areas. In general, $\mathrm{Zn}$ levels in the $0-10$ depth were considered satisfactory $\left(>1.5 \mathrm{mg} \mathrm{kg}^{-1}\right)$ in the planting areas and low in the non-managed areas, as well as $\mathrm{Mn}$ levels, for all depths. For Fe, the planting area showed higher levels compared to the non-managed area and the caiçaras in the three depths.

Table 1. Average values of $\mathrm{Cu}, \mathrm{Zn}, \mathrm{Mn}$, and Fe in three land management systems, at three depths (0-10, 10-20, and $20-30 \mathrm{~cm}$ ) in Aningal Indigenous Land, Roraima.

\begin{tabular}{ccccccccccccc}
\hline $\begin{array}{c}\text { Management System } \\
\text { Compartments }\end{array}$ & $\mathbf{C u} \mathbf{C n}$ & \multicolumn{9}{c}{$\mathbf{M n}$} & $\mathbf{F e}$ \\
\cline { 2 - 12 } & $\mathbf{0 - 1 0}$ & $\mathbf{1 0 - 2 0}$ & $\mathbf{2 0 - 3 0}$ & $\mathbf{0 - 1 0}$ & $\mathbf{1 0 - 2 0}$ & $\mathbf{2 0 - 3 0}$ & $\mathbf{0 - 1 0}$ & $\mathbf{1 0 - 2 0}$ & $\mathbf{2 0 - 3 0}$ & $\mathbf{0 - 1 0}$ & $\mathbf{1 0 - 2 0}$ & $\mathbf{2 0 - 3 0}$ \\
\hline \multirow{2}{*}{ Adjacent planting } & 1.50 & 1.02 & 0.89 & $5.12 \mathrm{a}$ & $2.93 \mathrm{a}$ & $2.04 \mathrm{a}$ & $38.2 \mathrm{a}$ & $25.6 \mathrm{a}$ & $21.0 \mathrm{a}$ & $245 \mathrm{a}$ & $223 \mathrm{a}$ & $175 \mathrm{a}$ \\
& $( \pm 0.33)$ & $( \pm 0.41)$ & $( \pm 0.33)$ & $( \pm 0.86)$ & $( \pm 1.10)$ & $( \pm 1.09)$ & $( \pm 10.3)$ & $( \pm 8.37)$ & $( \pm 8.39)$ & $( \pm 16)$ & $( \pm 22)$ & $( \pm 42)$ \\
\hline \multirow{2}{*}{ Caiçara } & 1.12 & 0.91 & 1.05 & $1.87 \mathrm{~b}$ & $1.29 \mathrm{~b}$ & $1.08 \mathrm{~b}$ & $13.6 \mathrm{~b}$ & $7.4 \mathrm{~b}$ & $5.5 \mathrm{~b}$ & $158 \mathrm{~b}$ & $146 \mathrm{~b}$ & $111 \mathrm{~b}$ \\
& $( \pm 0.24)$ & $( \pm 0.32)$ & $( \pm 0.34)$ & $( \pm 0.66)$ & $( \pm 0.39)$ & $( \pm 0.09)$ & $( \pm 5.49)$ & $( \pm 3.14)$ & $( \pm 2.55)$ & $( \pm 60)$ & $( \pm 50)$ & $( \pm 34)$ \\
\hline \multirow{2}{*}{ Non-managed area } & 084 & 1.54 & 0.69 & $1.09 \mathrm{~b}$ & $0.90 \mathrm{~b}$ & $0.37 \mathrm{~b}$ & $6.7 \mathrm{~b}$ & $3.7 \mathrm{~b}$ & $2.8 \mathrm{~b}$ & $81 \mathrm{c}$ & $82 \mathrm{~b}$ & $79 \mathrm{c}$ \\
& $( \pm 0.95)$ & $( \pm 0.87)$ & $( \pm 0.18)$ & $( \pm 0.46)$ & $( \pm 0.23)$ & $( \pm 0.08)$ & $( \pm 2.83)$ & $( \pm 1.57)$ & $( \pm 0.80)$ & $( \pm 11)$ & $( \pm 7)$ & $( \pm 8)$ \\
\hline
\end{tabular}

Data represent the mean of three sites \pm standard error. Subsequent columns with the same letter, at the same depth, in different soil management systems, do not differ at the $5 \%$ level of probability, according to the Duncan's test. 


\subsection{Soil Physical Attributes (Soil Texture, Bulk Density, and Total Porosity)}

In this study, only the $0-5 \mathrm{~cm}$ depth showed significant differences in soil bulk density values (Ds) (Table 2). The Ds in the adjacent plantings was statistically different to that of the other areas (caiçaras and non-managed area). In the 5-10 cm layer, no significant differences were found, despite the lower Ds in the planting area. In this depth, all of the three assessed areas showed Ds above critical levels. Reichert et al. proposed a critical Ds between 1.70 and $1.80 \mathrm{Mg} \mathrm{m}^{-3}$ for sandy loam soils [25], as studied here.

Table 2. Texture, soil bulk density, and total soil porosity under three soil management systems at two depths (0-5 and 5-10 cm), sampled in Aningal Indigenous Land, Roraima $(n=3)$.

\begin{tabular}{|c|c|c|c|c|c|c|c|}
\hline \multirow{2}{*}{$\begin{array}{l}\text { Management System } \\
\text { Compartments }\end{array}$} & \multirow{2}{*}{ Clay } & \multirow{2}{*}{ Silt } & \multirow{2}{*}{ Sand } & \multicolumn{2}{|c|}{ Ds } & \multicolumn{2}{|c|}{ TP } \\
\hline & & & & $0-5 \mathrm{~cm}$ & $5-10 \mathrm{~cm}$ & $0-5 \mathrm{~cm}$ & $5-10 \mathrm{~cm}$ \\
\hline & & $\mathrm{g} \mathrm{kg}^{-1}$ & & \multicolumn{2}{|c|}{$-\mathrm{Mg} \mathrm{m}^{-3}-$} & \multicolumn{2}{|c|}{$-\%-$} \\
\hline Adjacent planting & 153 & 153 & 694 & $1.50 \mathrm{~b}$ & 1.65 & $49.92 \mathrm{~b}$ & 37.43 \\
\hline Caiçara & 145 & 136 & 719 & $1.64 \mathrm{a}$ & 1.67 & $38.13 \mathrm{a}$ & 37.03 \\
\hline Non-managed area & 97 & 195 & 709 & $1.65 \mathrm{a}$ & 1.67 & $37.58 \mathrm{a}$ & 36.99 \\
\hline
\end{tabular}

Values followed by the same letter in the column, in each soil management systems, do not differ at the $5 \%$ level of probability, according to the Duncan's test. $(n=3)$. Ds = soil density; TP = total porosity.

In adjacent planting areas, soils at $0-5 \mathrm{~cm}$ depth had a total porosity (TP) of approximately $50 \%$, being significantly higher than the other systems. Soils in caiçaras and non-managed areas showed low TP values [26] of around $38.1 \%$ and $37.6 \%$, respectively, with no significant difference (Table 2).

\subsection{Graphical Analysis of Principal Components}

From the biplots of the principal components analysis, it is possible to observe an association between the soil characteristics at the depths of 10,20, and $30 \mathrm{~cm}$ in the three compartments studied in each retiro (caiçara, adjacent planting and non-managed area) (Figure 3). Within the $0-10 \mathrm{~cm}$ depth, the two principal components explained $72.2 \%$ of the total variability. Within the $10-20$ and $20-30 \mathrm{~cm}$ depths, the principal components explained $73.0 \%$ and $74.5 \%$ of the total variance, respectively. The graphs demonstrate the same trend as that observed in the 0-10 $\mathrm{cm}$ layer in terms of delimiting the three compartments of the management system. The most fertile soils were from planting areas, followed by caiçaras, and, finally, non-managed areas. These results indicate that agricultural soil management in caiçaras - and in their slightly lower adjacent areas-affects the fertility of soils up to $30 \mathrm{~cm}$ depth, especially for soil C, P, K, Ca, Mg, Zn, Fe, and Mn. 

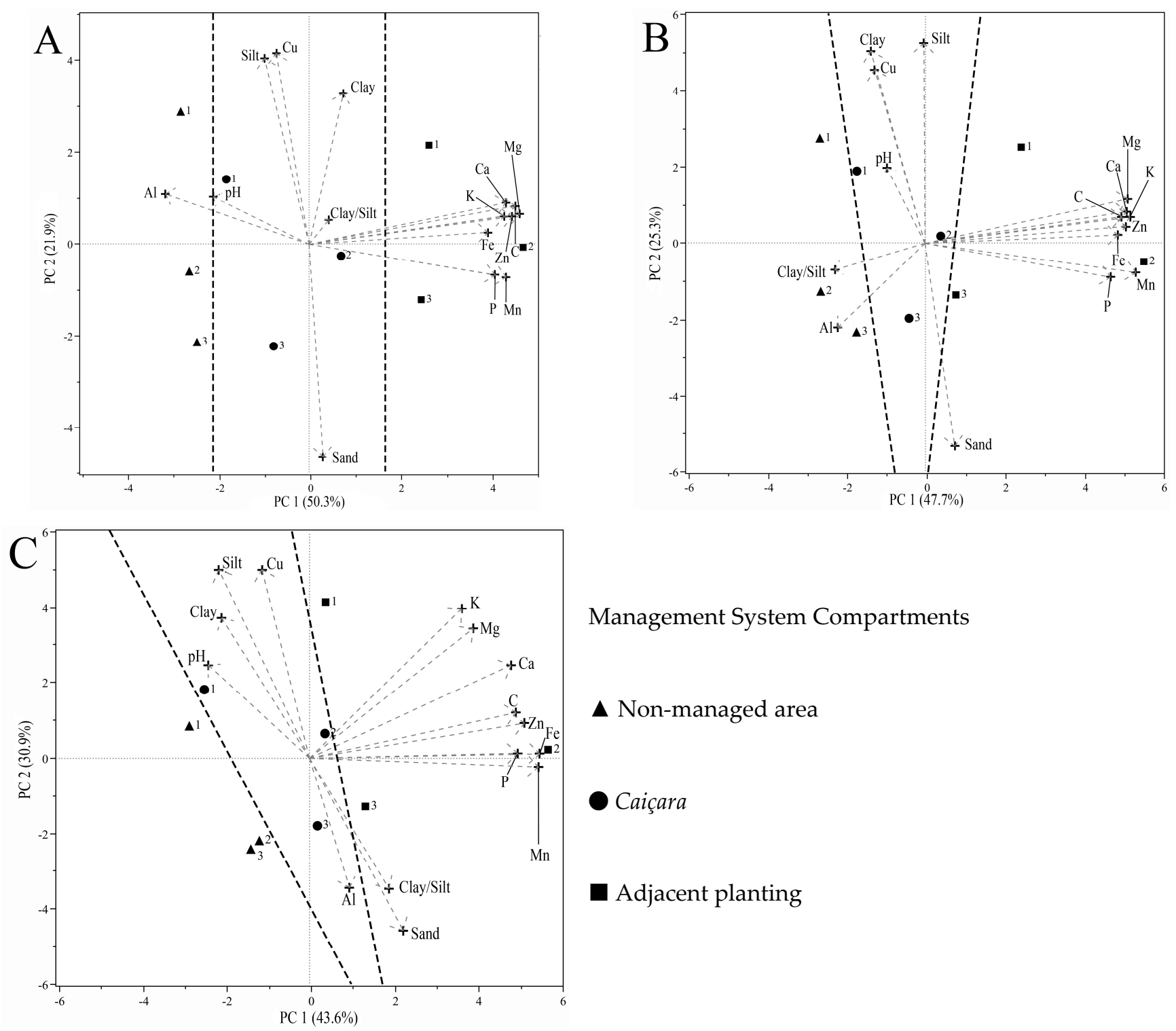

Management System Compartments

A Non-managed area

Caiçara

Adjacent planting

Figure 3. Biplot based on principal components in which interactions between soil traits and management systems are shown for three soil depths: 0-10 cm (A), 10-20 cm (B), and 20-30 (C). Aningal indigenous land, Roraima $(\mathrm{n}=3)$.

\section{Discussion}

\subsection{Acidity, Exchangeable Al, $\mathrm{Ca}, \mathrm{Mg}, \mathrm{K}$, Available P, and Organic C}

Except for $\mathrm{pH}(\mathrm{KCl})$ at the $0-10 \mathrm{~cm}$ layer, in general, the results of this study did not show changes in $\mathrm{pH}$ after organic fertilization with corral manure, as also observed by other authors [27-29]. However, other studies [30-32], more frequently, have shown an increase in soil $\mathrm{pH}$ with the use of organic waste of animal origin. Mitchel and Tu [33] claim that the addition of manure usually does not modify the $\mathrm{pH}$ of the soil, but when there is a continuing application of organic fertilizer over time, $\mathrm{pH}$ may significantly increase. According to Donagemma et al. [34], the lower buffering capacity of sandy soils can be considered an advantage for their agricultural use, when compared to clayey and very clayey soils, as they require less lime to correct the acidity of the soil [34]. On the other hand, the values found indicate low aluminum toxicity in the soils of this region, confirming the work of Pinho et al. [12].

The results obtained for $\mathrm{Ca}, \mathrm{Mg}$, and $\mathrm{K}$ confirm the beneficial effect of manure supply derived from the caiçaras in the adjacent planting areas, through superficial runoff, mainly in the $0-10 \mathrm{~cm}$ layer $[30,33,35]$, which can also be complemented by vegetation through 
nutrient cycling [36]. In the surface layer, Ca values in the planting area are considered of average fertility, and in the non-managed area, they are considered low, while Mg levels are considered high in the planting areas and low to medium in other areas [24]. The low $\mathrm{K}$ levels identified in the soil of non-managed areas may also be related to the higher sand content, which tends to decrease the concentration of this nutrient due to leaching $[30,31]$. $\mathrm{K}$ added to soil by manure is in a readily available form, does not form part of any stable organic compound, and is easily leached by rainwater [35,37].

According to Oliveira et al. [32], the addition of very large amounts of manure can result in an accumulation of $\mathrm{P}$ on the top soil, as also observed in this work. This accentuated increase in the $0-10 \mathrm{~cm}$ layer can also be linked to the accumulation of manure rich in $p$ over time and also because it is a poorly mobile nutrient in the soil [30]. This high availability may be associated with the fact that a high proportion of this nutrient in manure is in available forms [30,37]. Admitting $10 \mathrm{mg} \mathrm{kg}^{-1}$ as a high $p$ content, the values found in the planting area were high [24]. As observed in $96 \%$ of the soils in the Amazon, where $p$ deficiency is severe and widespread [38], the soils in the non-managed area of this study showed low levels of $p\left(p<3 \mathrm{mg} \mathrm{kg}^{-1}\right)$, highlighting that the use of cattle manure by indigenous farmers can significantly increase P levels in the poor soils of the Lavrado. On the other hand, a lower buffering capacity of these soils, both for $\mathrm{pH}$ and available $\mathrm{P}$, can be considered an advantage for their agricultural use when compared to clayey and very clayey soils, which have high $p$ adsorption capacity [39]. The results of this research follow the same trend as those of other studies that have demonstrated the gradual and positive effect of the use of cattle manure in soil fertilization, increasing the availability of nutrients to plants and favoring greater productivity $[27,30,32,33,35]$.

The results of organic $C$ show the beneficial effect of the supply of cattle manure to increase the organic matter in these soils, reaching values that are considered average in the topsoil [24]. The low levels of $C$ found in non-managed areas are within the range found by other authors for the same region [11], who attributed these values to the low clay content of these soils. In sandy soils, decomposition is generally faster because organic matter is more accessible to microorganisms, in contrast to clay soils, where organic matter can be more effectively combined in soil aggregates [34,40]. Seen in these terms, the management of organic matter is one of the main factors of sustainability for sandy soils, because it improves physical and chemical properties, increasing CEC, nutrient recycling, and water retention capacity $[39,41]$.

Results indicate that cattle management in caiçaras can create conditions for farming in Lavrado areas. As all indigenous communities in the Lavrado raise cattle, manure is an available resource for them, and this should be considered in government programs that recently have been supporting farming in Lavrado fields in Indigenous Lands. These programs have been providing inputs, such as machinery, chemical soil fertilizers, and hybrid crop seeds, but ignore manure. Planting in Lavrado areas is important to enhance production of surpluses as well as to diminish pressure on forest areas where traditional fields are installed (swidden-fallow production). If crop fields in the Lavrado follow agroecological guidance, it will be possible to maintain the sustainability inherent to indigenous systems and the connection to traditional knowledge, along with environmental conservation. Beyond the use of manure for planting crops, integration with livestock can be accomplished in more sustainable systems, such as agroforestry systems.

\subsection{Micronutrients ( $\mathrm{Cu}, \mathrm{Zn}, \mathrm{Mn}$, and $\mathrm{Fe}$ )}

The levels of $\mathrm{Cu}$, for all areas and depths, are similar to those found by Pinho et al. [11] demonstrating that this is not a limiting nutrient in the soil of the Lavrado region as it is in the Brazilian Cerrado, possibly due to the composition of the source material. The micronutrients $\mathrm{Cu}, \mathrm{Zn}$, and $\mathrm{Mn}$ can become concentrated in the soil in bioavailable ways through connection with organic and mineral forms of the soil [41], and these reactions are dependent on $\mathrm{pH}$. The interaction of micronutrients with mineral forms in the soil, 
especially in sandy soils, such as those in the studied region, causes less availability of the former [42].

Along with the native pasture of the Lavrado, which has low nutritional quality, the cattle raised by the indigenous communities receive as supplementary feed a mineral salt that may contain mineral sources of calcium, phophorus, copper, zinc, magnesium, sodium, and potassium, mixed with common salt. This supplementary feed is undertaken only in the dry season and may influence the chemical characteristics of cattle's manure during that period.

Thus, the addition of manure can contribute to the increment of micronutrients, primarily of Mn and Fe in the soils of the Lavrado.

\subsection{Soil Physical Attributes (Soil Texture, Bulk Density, and Total Porosity)}

Livestock farming is traditionally associated with loss of soil physical quality, a result of animal trampling, which leads to an increase in soil bulk density [43]. According to Lanzanova et al. [44] an effect of animal trampling on the physical properties of soil is limited to its most superficial layers. In general, soils in their natural state, under native vegetation, have agronomically desirable physical characteristics, such as permeability, structure, soil bulk density, and porous space [45]. In the present study, soils under native vegetation (non-managed areas) did not have adequate physical properties, as some of the Ds values found were considered high, besides low total porosity (TP). TP values below 50\% are considered low [26] and can prejudice soil water storage, root system development, and gas exchange. In a natural savanna in Roraima, Cruz et al. [43] found Ds values below those found in the present study ( $\mathrm{Ds}=1.55 \mathrm{Mg} \mathrm{m}^{-3}$ ), while in savanna converted to pasture, Ds values followed the same trend as that observed in the present study (Ds $=1.65 \mathrm{Mg} \mathrm{m}^{-3}$ ).

It can be noticed that the extensive cattle management practiced by the indigenous people of the Lavrado has low impacts on the soil physical properties. Despite the trampling during cattle confinement, no significant changes in soil bulk density nor any increase in compaction were observed. Although cattle management practices are not directly linked to the degradation of soil quality, soils of Lavrado have physical characteristics values (such as high soil bulk density and low total porosity) that, if not well managed, may hinder the management and establishment of crops and more demanding native species. This is one more characteristic that indicates agroforestry systems for Lavrado fields, once multi-strata trees create a root system that occupies diverse layers in the soil, helping to maintain soil porosity [36].

\subsection{Graphical Analysis of Principal Components}

The representation of Cartesian limits by straight lines allowed for a distinction between the three compartments of the management system. On the right side of the graph is the 'Planting' compartment, in the middle the 'Caiçara', and on the left side the 'non-managed area'. The direction of most macro and micronutrient vectors points towards the right side, indicating that soils in planting areas are the most fertile, followed by caiçaras and, lastly, by non-managed areas. The $\mathrm{pH}$ and $\mathrm{Al}$ vectors point toward the left, which indicates that higher $\mathrm{pH}$ and $\mathrm{Al}$ values are associated with non-managed areas, followed by caiçaras, and finally by planting areas. This confirms that $\mathrm{pH}$ was one of the few attributes of the soil that was not altered by organic fertilization with cattle manure, as also observed by other authors [27-29]. The directions of the soil texture vectors tended to form 90 degrees angles with the nutrient vectors, which indicates no association between the soil texture and nutrients, which could be related to the low nutrient retention, such as $\mathrm{K}$ and $\mathrm{N}$ [46], mainly in the sandy textured soils, such as those studied here [34]. The biplot, therefore, confirms the efficiency of manure runoff in improving topsoil fertility, only requiring the $\mathrm{pH}$ to be managed.

Regarding the association among $\mathrm{Al}$, nutrients, and management vectors, the $\mathrm{Al}$ vector rotated with depth, from $\sim 180^{\circ}(0-10 \mathrm{~cm})$ to $\sim 90^{\circ}(20-30 \mathrm{~cm})$; this means this vector pointed 
only to non-managed areas in the $0-10 \mathrm{~cm}$ layer but pointed to caiçara in the 20-30 cm layer. This indicates a relation between $\mathrm{Al}$ and nutrients that is inversely proportional to the 0-10 cm layer and independent in the 20-30 cm layer, and in the deeper layers, the content of $\mathrm{Al}$ relative to nutrients begins to increase even in caiçara and adjacent planting areas. This may be related to a slight liming effect caused by cattle manure in the surface layer, as well as being a nutrient source [28]. It was also observed that the Al vector was associated with the vector "sand" at the greatest depth, which indicates an increase in this fraction in depth, as well as a lower retention capacity of other nutrients due to a sandier texture.

\section{Conclusions}

The manure runoff in the cultivated area led to significant accumulations of organic $\mathrm{Ca}, \mathrm{Mg}, \mathrm{K}, \mathrm{P}, \mathrm{C}$, and micronutrients in the soil, without, however, affecting soil $\mathrm{pH}$.

Only the soil surface $(0-5 \mathrm{~cm})$ showed improvements in soil bulk density and total porosity. The physical properties of the soil were not affected in the depth $5-10 \mathrm{~cm}$.

The intensified management of caiçaras, combined with cropping in an adjacent area, demonstrate how efficient the management practices applied by the indigenous cattle raisers can be at exploiting available resources to improve soil fertility, allowing for the cultivation of useful species in soils in areas of the Lavrado that were originally of low fertility. This is particularly important in the context of indigenous lands in this region, where traditional agricultural practices (mainly slash and burn agriculture) are carried out in forest areas that are scarce near many communities in Lavrado. Thus, the development of practices that enable cultivation in non-forested Lavrado areas is extremely important to reduce the pressure on forested areas - mainly forest islands and riparian forests - which are already under severe use pressure in many communities.

The existence of planting areas adjacent to the caiçaras shows the indigenous perception of the effects of manure on soil fertility and the response of plants to these effects, especially in relation to banana, a plant that clearly responds to soils that are rich in potassium. In addition to the management of caiçaras representing a creative alternative found for raising cattle and improving the diet of local people, this management also shows that indigenous communities absorbed livestock and adapted it to their reality, revealing an interesting process of adaptation and control of the relationships that involved them in an interethnic context.

Author Contributions: All authors helped shape the research and the analysis of the manuscript. Conceptualization, L.V.C.G., R.C.P. and S.S.A.; methodology, L.V.C.G., A.F.N.J. and S.S.A.; software, L.V.C.G. and C.A.T.-B.; validation, L.V.C.G.; formal analysis, L.V.C.G. and H.d.S.P.; investigation, L.V.C.G., R.C.P. and M.I.C.A.; resources, L.V.C.G. and S.S.A.; data curation, L.V.C.G.; writing original draft preparation, L.V.C.G. and M.I.C.A.; writing-review and editing, all authors; visualization, L.V.C.G. and H.d.S.P.; supervision, S.S.A.; project administration, S.S.A. and L.V.C.G.; funding acquisition, L.V.C.G. All authors have read and agreed to the published version of the manuscript.

Funding: This research was funded by Amazonas State Research Support Foundation (FAPEAM/ Process No. 062.00855/2019); Coordination for the Improvement of Higher Education Personnel (CAPES) and the European Union, through the Institute for Society, Population, and Nature-ISPN.

Institutional Review Board Statement: The study was conducted according to the guidelines of the Declaration of Helsinki, and approved by the National Commission for Ethics in Research-CONEP (CAAE: 02665712.4.0000.0006. Opinion 444.506), and the National Indian Foundation-FUNAI (Process: 052669/2013-33. Authorization: 33/AAEP/PRES/2013). As this research involved access to traditional knowledge and entry into Indigenous Territory, authorizations were obtained from the Genetic Heritage Management Council-CGEN/MMA (Authorization: 02000.000654/2012-19).

Informed Consent Statement: Informed consent was obtained from all subjects involved in the study.

Data Availability Statement: Not applicable. 
Acknowledgments: We thank the indigenous farmers of the Aningal Indigenous Land, without whom this research would not have been possible; Tuxaua Raildo, for his hospitality and support in collecting the soil, and the residents who accepted to participate in the interviews, always interested in telling the story of the community; and the INPA team of the soil analysis laboratory, for their support in the analyzes.

Conflicts of Interest: The authors declare no conflict of interest.

\section{References}

1. Barbosa, R.I.; Campos, C.; Pinto, F.; Fearnside, P. The "Lavrados" of Roraima: Biodiversity and Conservation of Brazil's Amazonian Savannas. Funct. Ecosyst. Communities 2007, 1, $29-41$.

2. Campos, C. As pequenas TIs de Roraima. In Povos Indígenas do Brasil-2006-2010; Ricardo, B., Ricardo, F., Eds.; Instituto Sociambiental: São Paulo, Brazil, 2011; pp. 260-263.

3. Barbosa, R.I.; Miranda, I.S. Fitofisionomias e diversidade vegetal das savanas de Roraima. In Savanas de Roraima: Etnoecologia, Biodiversidade e Potencialidades Agrossilvipastoris; Barbosa, R.I., Xaud, H.A.M., Costa e Sousa, J.M., Eds.; FEMACT: Boa Vista, Brazil, 2005; pp. 61-77.

4. Jaramillo, M.M.A. Estrutura, Biomassa Arbórea e Composição Florística de Ilhas de Mata da Savana de Roraima, Norte da Amazônia Brasileira. Master's Thesis, Federal University of Roraima, Boa Vista, Brazil, 2015; p. 57. Available online: http:/ / www.bdtd.ufrr.br/tde_busca/arquivo.php?codArquivo=277 (accessed on 22 September 2020).

5. Santos, N.M.C.; Vale Júnior, J.F.; Barbosa, R.I. Florística e estrutura arbórea de ilhas de mata em áreas de savana do norte da Amazônia brasileira. Bol. Mus. Para. Emílio Goeldi. Cienc. Nat. 2013, 8, 205-221. Available online: http:/ / editora.museu-goeldi. br/bn/artigos/cnv8n2_2013/floristica(santos).pdf (accessed on 24 September 2020).

6. Feitosa, K.K.A.; Vale Junior, J.F.; Schaefer, C.E.G.R.; Sousa, M.I.L.; Nascimento, P.P.R.R. Relações solo-vegetação em "ilhas" florestais e savanas adjacentes no nordeste de Roraima. Ciênc. Florest. 2016, 26, 135-146. Available online: https: / www.scielo. $\mathrm{br} / \mathrm{pdf} / \mathrm{cflo} / \mathrm{v} 26 \mathrm{n} 1 / 0103-9954-\mathrm{cflo}-26-01-00135 . p d f$ (accessed on 22 September 2020). [CrossRef]

7. Melo, D.F.; Gianlupi, D.; Uchôa, S.C.P. Características edafológicas dos solos do Estado de Roraima. Embrapa Roraima: Boa Vista, Brazil (Boletim de Pesquisa e Desenvolvimento, 1). 2003; p. 32. Available online: https:/ / ainfo.cnptia.embrapa.br/digital/ bitstream/item/174226/1/BP012003-solos-roraima-valdinar.pdf (accessed on 20 September 2020).

8. Vale Júnior, J.F.; Souza, M.I.L. Caracterização e distribuição dos solos das savanas de Roraima. In Savanas de Roraima: Etnoecologia, Biodiversidade e Potencialidades Agrossilvipastoris; Barbosa, R.I., Xaud, H.A.M., Costa e Sousa, J.M., Eds.; FEMACT: Boa Vista, Brazil, 2005; pp. 79-92.

9. Pinho, R.C.; Pedreira, J.L.; Rocha, J.C.; Perez, I.U.; Hada, A.R.; Miller, R.P.; Alfaia, S.S. Agroextrativismo indígena no Lavrado: O caso da TI Araçá, RR. In Amazônia: Terra e Água-Degradação e Desenvolvimento Sustentável; Scarlato, F.C., Evangelista, R.A.O., Araújo, W.F., Eds.; Federal University of Roraima: Boa Vista, Brazil, 2012; pp. 143-164.

10. Pedreira, J.L.; Hada, A.R.; Perez, I.U.; Pinho, R.C.; Miller, R.; Alfaia, S.S.; Albuquerque, C.Y. Produção de alimentos e conservação de recursos naturais na Terra Indígena Araçá, Roraima. In Etnobiologia e Saúde de Povos Indígenas; Haverroth, M., Ed.; NUPEA: Recife, Brazil, 2013; pp. 1-17.

11. Pinho, R.C.; Alfaia, S.S.; Miller, R.P.; Uguen, K.; Magalhães, L.D.; Ayres, M.I.C.; Freitas, V.; Trancoso, R. Islands of fertility: Soil improvement under indigenous homegardens in the savannas of Roraima, Brazil. Agrofor. Syst. 2011, 81, 235-247. [CrossRef]

12. Santilli, P. Pimenta nos olhos. In Povos Indigenas do Brasil-2006-2010; Ricardo, B., Ricardo, F., Eds.; ISA: São Paulo, Brazil, 2011; pp. 257-259.

13. Gonçalves, L.V.C.; Alfaia, S.S.; Dias, C.M.O., Jr. Manejo das Caiçaras Indígenas: Uma prática agropecuária no Lavrado de Roraima, Amazônia Brasileira. Mundo Amaz. 2019, 10, 187-207. [CrossRef]

14. Campos, C. Diversidade Socioambiental de Roraima: Subsídios Para Debater o Futuro Sustentável da Região; ISA: São Paulo, Brazil, 2011; p. 64.

15. Vieira, J.G. Missionários, Fazendeiros e Índios em Roraima: A Disputa Pela Terra-1777 a 1980; Editora UFRR: Boa Vista, Brazil, 2007; $248 \mathrm{p}$.

16. Oliveira, R.S. A Criação de Boi em Terras Indígenas do Lavrado. Master's Thesis, Federal University of Roraima, Boa Vista, Brazil, 2018; p. 121. Available online: http://repositorio.ufrr.br:8080/jspui/handle/prefix/266 (accessed on 16 September 2020).

17. Adams, C. As populações caiçaras e o mito do bom selvagem: A necessidade de uma nova abordagem interdisciplinar. Rev. Antropol. 2000, 43, 145-182. [CrossRef]

18. Sampaio, T. O Tupi na Geografia Nacional; Brasiliana: Brasília, Brazil, 1987; p. 359.

19. Morales Torres, V. El Corral Itinerante: Una Tecnología Campesina Para el Manejo de la Fertilidade de los Suelos en los Andes; AGRUCO: Cochabamba, Bolívia, 1993; p. 35. Available online: http://atlas.umss.edu.bo:8080/xmlui/bitstream/handle/123456789/182/ corral.pdf.pdf?sequence=1\&isAllowed=y (accessed on 12 September 2020).

20. Klemmedson, J.; Tiedemann, A. Soil and vegetation development in an abandoned sheep corral on degraded subalpine rangeland. Great Basin Nat. 1994, 54, 301-312. Available online: http:/ / www.jstor.org/stable/41712846 (accessed on 20 October 2020).

21. FUNAI. 2013. Available online: https:/ / www.mapas.funai.gov.br (accessed on 7 October 2018).

22. $\quad$ EMBRAPA. Manual Métodos de Análise de Solos, 2nd ed.; EMBRAPA: Rio de Janeiro, Brazil, 2011; p. 230. 
23. Lemos, R.C.; Santos, R.D. Manual de Descrição e Coleta de Solo no Campo, 3rd ed.; Sociedade Brasileira de Ciência do Solo: Campinas, Brazil, 1996; p. 84.

24. Cochrane, T.T.; Sánchez, L.G.; Azevedo, L.G.; Porras, J.A.; Garver, C.L. Land in Tropical América; CIAT/Embrapa: Cali, Colombia, 1985; Available online: https:/ / www.embrapa.br/busca-de-publicacoes/-/ publicacao/549413/land-in-tropical-america (accessed on 22 September 2020).

25. Reichert, J.M.; Reinert, D.J.; Braida, J.A. Qualidade dos Solos e Sustentabilidade de Sistemas Agrícolas. Ciênc. Ambiente 2003, 27, 29-48. Available online: http://www.fisicadosolo.ccr.ufsm.quoos.com.br/downloads/Producao_Artigos/5.pdf (accessed on 25 August 2021).

26. Brady, N.C.; Weil, R.R. The Nature and Properties of Soils, 12rd ed.; Prentice Hall: Hoboken, NJ, USA, $1999 ;$ p. 881.

27. Silva, J.; Lima e Silva, P.S.; Oliveira, M.; Barbosa e Silva, K.M. Efeito de esterco bovino sobre os rendimentos de espigas verdes e de grãos de milho. Hortic. Bras. 2004, 22, 326-331. [CrossRef]

28. Naramabuye, F.X.; Haynes, R.J.; Modi, A.T. Cattle manure and grass residues as liming materials in a semi-subsistence farming system. Agric. Ecosyst. Environ. 2008, 124, 136-141. [CrossRef]

29. Muraishi, C.T.; Alves, M.C.; Silva Júnior, A.; Souza, Z.M. Chemical attributes of a savannah Typic Hapludox soil under management systems. Acta Sci. Agron. 2011, 33, 551-557. [CrossRef]

30. Galvão, S.R.S.; Salcedo, I.H.; Oliveira, F.F. Acumulação de nutrientes em solos arenosos adubados com esterco bovino. Pesqui. Agropecu. Bras. 2008, 43, 99-105. Available online: https://www.scielo.br/j/pab/a/6Qb8ZzZ8jBftBQ3XcFXCqNb/?format=pdf\& lang=pt (accessed on 16 September 2020). [CrossRef]

31. Higashikawa, F.S.; Silva, C.A.; Bettiol, W. Chemical and Physical Properties of Organic Residues. Rev. Bras. Cienc. Solo 2010, 34, 1743-1752. [CrossRef]

32. Mantovani, J.R.; Carrera, M.; Moreira, J.L.A.; Marques, D.J.; Silva, A.B. Fertility properties and leafy vegetable production in soils fertilized with cattle manure. Rev. Caatinga 2017, 30, 825-836. [CrossRef]

33. Mitchell, C.C.; Tu, S. Nutrient accumulation and movement from poultry litter. Soil Sci. Soc. Am. J. 2006, 70, 2146-2153. Available online: https:/ /www.scielo.br/j/hb/a/FwKvycspxMZFCXzLxrPQ96c/?format=pdf\&lang=en (accessed on 22 September 2020). [CrossRef]

34. Donagemma, G.K.; Freitas, P.L.; Balieiro, F.C.; Fontana, A.; Spera, T.S.; Lumbreras, J.F.; Viana, J.H.; Araújo Filho, J.C.; Santos, F.C.; Albuquerque, M.R.; et al. Characterization, agricultural potential, and perspectives for the management of light soils in Brazil. Pesqui. Agropecu. Bras. 2016, 51, 1003-1020. [CrossRef]

35. Oliveira, F.F.; Salcedo, I.H.; Galvão, S.R.S. Adubação orgânica e inorgânica de batatinha em solos arenosos: Produtividade, nutrientes na planta e lixiviação. Rev. Bras. Eng. Agríc. Ambient. 2011, 15, 1228-1234. [CrossRef]

36. Pinho, R.C.; Miller, R.P.; Alfaia, S.S. Agroforestry and the Improvement of Soil Fertility: A View from Amazonia. Appl. Environ. Soil Sci. 2012, 2012, 616383. [CrossRef]

37. Eckhardt, D.P.; Redin, M.; Santana, N.A.; Conti, L.; Dominguez, J.; Jacques, R.J.S.; Antoniolli, Z.I. Cattle manure bioconversion effect on the availability of nitrogen, phosphorus, and potassium in soil. Rev. Bras. Cienc. Solo 2018, 42, e0170327. [CrossRef]

38. Sanchez, P.A.; Salinas, J.G. Low input management technology for managing Oxisols and Ultisols in tropical America. Adv. Agron. 1981, 34, 279-406. [CrossRef]

39. Silva, P.S.L.; Silva, J.; Oliveira, F.H.T.; Sousa, A.K.F.; Duda, G.P. Residual effect of cattle manure application on green ear yield and corn grain yield. Hortic. Bras. 2006, 24, 166-169. [CrossRef]

40. Desjardins, T.; Carneiro Filho, A.; Mariotti, A.; Girardin, A.C.C. Changes of the forest-savanna boundary in Brazilian Amazonia during the Holocene revealed by stable isotope ratios of soil organic carbon. Oecologia 1996, 108, 749-756. [CrossRef]

41. Girotto, E.; Ceretta, C.A.; Brunetto, G.; Santos, D.R.; Silva, L.S.; Lourenzi, C.R.; Lorensini, F.; Vieira, R.C.B.; Schmatz, R. Acúmulo e formas de cobre e zinco no solo após aplicações sucessivas de dejeto líquido de suínos. Rev. Bras. Cienc. Solo 2010, 34, 955-965. [CrossRef]

42. Bissani, C.A.; Bohnen, H. Micronutrientes. In Fertilidade dos Solos e Manejo da Adubação de Culturas; Bissani, C.A., Gianello, C., Tedesco, M.J., Camargo, F.A.O., Eds.; Genesis: Porto Alegre, Brazil, 2004; pp. 221-237.

43. Cruz, D.L.S.; Vale Junior, J.F.; Cruz, P.L.S.; Cruz, A.B.S.; Nascimento, P.P.R.R. Atributos físico-hídricos de um Argissolo Amarelo sob floresta e savana naturais convertidas para pastagem em Roraima. Rev. Bras. Cienc. Solo 2014, 38, 307-314. [CrossRef]

44. Lanzanova, M.E.; Nicoloso, R.S.; Lovato, T.; Eltz, F.L.F.; Amado, T.J.C.; Reinert, D.J. Atributos físicos do solo em sistema de integração lavoura-pecuária sob plantio direto. Rev. Bras. Cienc. Solo 2007, 31, 1131-1140. [CrossRef]

45. Andreola, F.; Costa, L.M.; Olszevski, N. Influência da cobertura vegetal de inverno e da adubação orgânica e, ou, mineral sobre as propriedades físicas de uma terra roxa estruturada. Rev. Bras. Ciênc. Solo 2000, 24, 857-865. [CrossRef]

46. Lilienfein, J.; Wilcke, W.; Vilela, L.; Ayarza, M.A.; Lima, S.C.; Zech, W. Soil Fertility under Native Cerrado and Pasture in the Brazilian Savanna. Soil Sci. Soc. Am. J. 2003, 67, 1195-1205. [CrossRef] 